DOI $10.15421 / 4220010$

UDC 539.3:612.76

\author{
O. V. Pogrebnoy
}

\title{
MODELING OF INFLUENCE OF EXTERNAL FORCES AND STRUCTURAL FACTORS ON BIOMECHANICAL SYSTEM ELEMENT DAMAGE
}

The peculiarities of integrity damage of biomechanical system element under external forces nave been studied. The radiocarpal joint which is a part of the wrist joint was considered as a biomechanical system. The element of radiocarpal joint that subjected to integrity damage or significant destruction is radius bone. The structure change depending on time is taken into account. The initial data were roentgenograms of damaged areas of the biomechanical system element. The gender factor influence was under examination too. The dependences of fracture types for patient groups were established.

Keywords: modeling, biomechanical system; radiocarpal joint; radius bone; roentgenogram; fracture in typical place; fracture types; osteoporosis.

Introduction. Injuries to the wrist joint and hand are frequent skeletal injuries, accounting for at least $35 \%$ of the total number of limb injuries. In addition, in many cases, they lead to a long-term limitation of working capacity, and sometimes to disability [4]. The patients are both older people with active lifestyle and younger people subjected to high energy trauma. At the same time, there is obvious tendency to an increase in the number of cases of injuries under consideration among patients over 50 years old, especially women [2]. Osteoporosis is one of the predisposing factors for the increase in the frequency of fractures in old age. An important risk factor for fractures should be considered an increase in the number of falls in the elderly, which occur in domestic conditions from the height of their own growth [18].

Literature data indicate that up to $51.7 \%$ of injuries occur between the ages of 40 and 60 , and $43.8 \%$ are persons over 60 . The higher frequency and more complex nature of fractures in old age are undoubtedly associated with age-related metabolic changes in bone tissue [7].

Fractures of the distal epiphysis of the radial bone (RB) are the most common injuries to the wrist joint and involve the articular surfaces of the distal radial and wrist joints in $50-55 \%$ of cases [16]. There are four main components of the fracture: the diaphysis of RB, the styloid process of RB, the dorsal and palmar medial fragments. Two medial fragments, firmly connected by ligaments with the wrist and the styloid process of RB, make up the medial complex [3].

Traditionally, all fractures of the distal metaepiphysis of RB are divided into extensor (Colles fractures), flexion (Smith fractures) and impacted. 
Currently, in clinical practice, the classification AO / ASIF has become widespread, which allows to determine not only the type of fracture, but also serves as an algorithm for choosing treatment tactics [16, 18].

According to the AO / ASIF classification, all fractures are divided into three main types: type A - extra-articular fractures, type B - incomplete intraarticular fractures of the radius and type $\mathrm{C}$ - complete intra-articular fractures. The applied universal approach to the standardization of limb fractures, including the distal metaepiphysis of RB, made this classification widely used in the daily practice of traumatologists all around the world [7].

A large-scale clinical and epidemiological study of the prevalence of bone fractures and the results of their treatment, carried out in our geographical region, showed, in particular, that the most common fractures among the bones of the upper limb are fractures of RB - 36.5\% (for victims of all ages). In the age groups $40-59$ years old and $60+, \mathrm{RB}$ fractures are $44.1 \%$ and $46.2 \%$, respectively [8].

Object of investigation. The wrist joint is complex in terms of the number of bones involved in it, and in terms of the shape of the articular surfaces, it belongs to the elliptical joint with two axes of rotation (sagittal and frontal). Even minor changes in this joint cause limitation of function and deterioration in the quality of life [1].

Apparently, the concept of "wrist joint" is not entirely complete from an anatomical point of view. In Russian-language literature, the name "wrist joint" is used. The wrist joint is only a part of the combined wrist joint which is complex in form and function [6]. The concept of the wrist joint includes the joints of the bones of the forearm, radiocarpal, intercarpal and carpometacarpal joints with the corresponding system of the capsuleligamentous apparatus [1]. The wrist joint and its main elements are shown schematically in Fig. 1.

Stress fractures are divided into two groups: fatigue, occurring as a result of a strong impact, and failure fractures, arising from normal pressure applied to a bone with insufficient elasticity (for example, osteoporotic bone) [4].

Fractures of RB in a typical (classical) location are localized in the distal part of the bone. There are two main types of fractures, depending on the mechanism of injury.

1. Colles fracture - extension fracture (Fig. 2). It occurs when falling on an unbent hand. The distal fragment is displaced to the back. It is the most common fracture of $\mathrm{RB}$, about $80 \%$ of cases. It was described for the first time in 1814 year by the Irish surgeon and anatomist A. Colles.

2. Smith fracture - flexion fracture (Fig. 2). It occurs when falling on a bent hand. The distal fragment is displaced to the palmar side. It was described for the first time in 1841 year by R.W. Smith.

The left hand is more often affected to fractures of RB.

The radiograph of a fracture of RB in a typical location is shown in Fig. 3.

The purpose of the work is to simulate the features of damage of the integrity of an element of the biomechanical system, which is under the external force and the influence of internal factors. 
Problem statement, initial data. The initial experimental material was 318 roentgenograms of patients with damages of the distal metaepiphysis of RB.

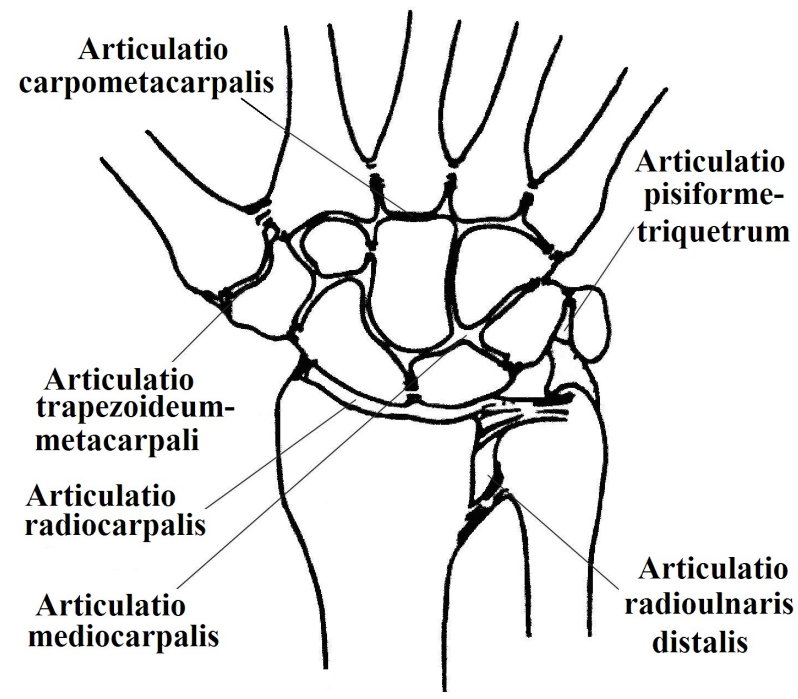

Fig. 1 - Carpal joint

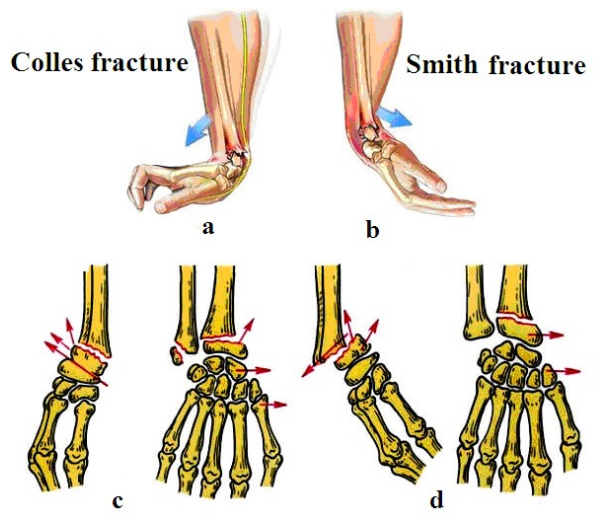

Fig. 2 - Main types of fractures of RB in a typical location

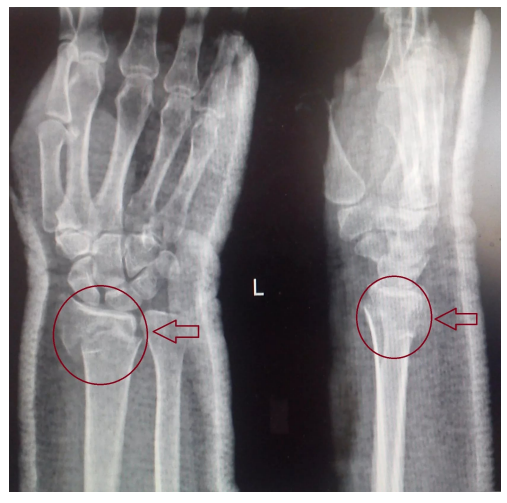

Fig. 3 - Roentgenogram of fracture of RB in a typical location

The total number of patients was 47 men and 271 women. Injuries were classified according to the AO / ASIF classification [11,12], as well as according to the simplified $A B C$ distribution scheme. Data on the distribution of the number of patients depending on the type of fracture and gender are given in [15]. Since the types of fractures are qualitative signs, each type is assigned a conditional rank in descending order of the sign [5]. Types of fractures with corresponding ranks are given in [15]. Average ranks of 
fractures according to the AO / ASIF classification and types A, B, C calculated as arithmetic means are presented in table 1. For a detailed study, patients were divided into ten-year age intervals.

Table 1 - Data about patients divided into ten-year age intervals

\begin{tabular}{|c|c|c|c|c|c|c|c|c|c|c|c|c|c|}
\hline \multirow{3}{*}{ № } & \multirow{3}{*}{ Age } & \multicolumn{6}{|c|}{ Male } & \multicolumn{6}{|c|}{ Female } \\
\hline & & \multirow{2}{*}{\begin{tabular}{|c} 
Rank \\
average \\
AO / \\
ASIF
\end{tabular}} & \multirow{2}{*}{$\begin{array}{c}\text { Rank } \\
\text { average } \\
\mathrm{A}, \mathrm{B}, \mathrm{C}\end{array}$} & \multicolumn{4}{|c|}{ Quantity } & \multirow{2}{*}{$\begin{array}{c}\text { Rank } \\
\text { average } \\
\text { AO / } \\
\text { ASIF }\end{array}$} & \multirow{2}{*}{$\begin{array}{c}\text { Rank } \\
\text { average } \\
\mathrm{A}, \mathrm{B}, \mathrm{C}\end{array}$} & \multicolumn{4}{|c|}{ Quantity } \\
\hline & & & & A & B & C & $\Sigma$ & & & A & B & C & $\Sigma$ \\
\hline 1 & 2 & 3 & 4 & 5 & 6 & 7 & 8 & 9 & 10 & 11 & 12 & 13 & 14 \\
\hline 1 & $20-29$ & 1.5 & 1 & 4 & 0 & 0 & 4 & 6 & 1.8 & 3 & 0 & 2 & 5 \\
\hline 2 & $30-39$ & 2.83 & 1.33 & 5 & 0 & 1 & 6 & 5.15 & 1.54 & 19 & 0 & 7 & 26 \\
\hline 3 & $40-49$ & 2.79 & 1.21 & 16 & 2 & 1 & 19 & 1.97 & 1 & 39 & 0 & 0 & 39 \\
\hline 4 & $50-59$ & 3 & 1.29 & 6 & 0 & 1 & 7 & 3.28 & 1.25 & 70 & 2 & 9 & 81 \\
\hline 5 & $60-69$ & 3.67 & 1.67 & 4 & 0 & 2 & 6 & 4.2 & 1.37 & 64 & 6 & 12 & 82 \\
\hline 6 & $70-70$ & 5.6 & 2 & 2 & 1 & 2 & 5 & 5.19 & 1.54 & 18 & 2 & 6 & 26 \\
\hline 7 & $80-89$ & - & - & 0 & 0 & 0 & 0 & 4.67 & 1.42 & 9 & 1 & 2 & 12 \\
\hline$\Sigma$ & - & - & - & 37 & 3 & 7 & 47 & - & - & 222 & 11 & 38 & 271 \\
\hline
\end{tabular}

Research results and their analysis. Based on the data given in table 1 , the dependences shown in Fig. 4 - Fig. 7 were built.

The dependence of the type of fracture according to the AO / ASIF classification on the average age for the type of fracture of all 318 patients is shown in Fig. 4. The equation of the trend line: $x=52.63-2963.68$. In the trend line equations in Fig. 4 - Fig. 6 the $x$ variable (fracture type) is horizontal, the variable $y$ (average age of patients) is vertical.

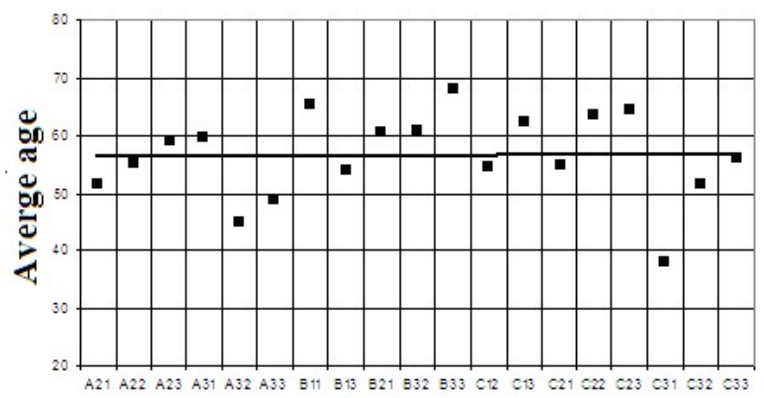

Fracture type

Fig. 4 - Dependence of the type of fracture according to the AO / ASIF classification on the average age of all 318 patients

The dependence of the fracture type on the age of the total number of female patients is shown in Fig. 5. The equation of the trend line: $x=4 y-238.44$.

The dependence of the fracture type on the average age of female patients of the older (50+) age group is shown in Fig. 6 . The equation of the trend line: $x=0213 y-129.26$. 
The dependences of the average ratings according to the AO / ASIF classification (indicated by squares) and types A, B, C (indicated by circles) on the age intervals in male patients are shown in Fig. 7. The equations of the trend line for the upper dependence is $x=1.52 y-1.38$, for the lower dependence: $x=5.88 y-4.76$.

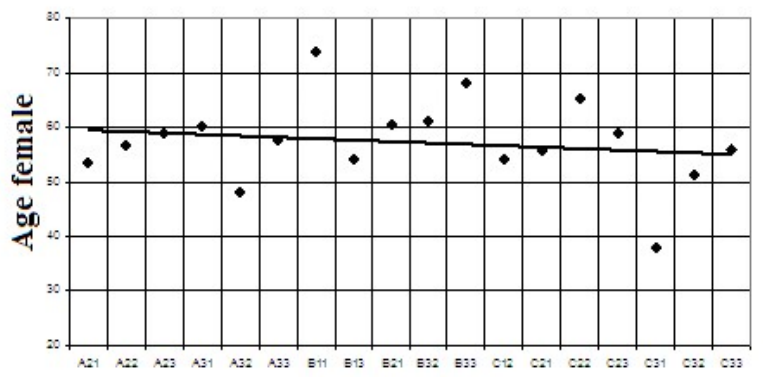

Fracture type

Fig. 5 - Dependence of the fracture type on the age of all female patients

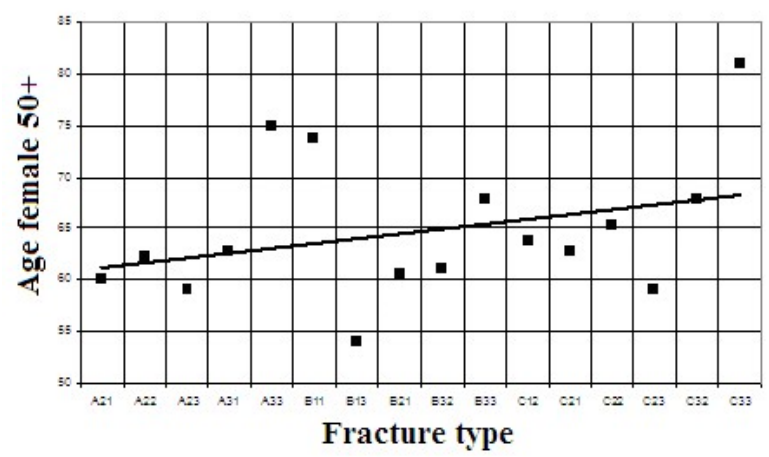

Fig. 6 - Dependence of the fracture type on the average age of female patients of the older age group

Note that for the entire sample of 318 patients, all types of fractures according to the AO / ASIF classification occurred with a constant average age of 56.3 years for the fracture type. However, when identifying individual groups of patients, various trends were revealed. Let us note the tendency of an increase in the age of female patients of the older group during the transition from extra-articular to intra-articular fractures. For the whole number of women, the opposite trend is observed.

According to the AO / ASIF classification, 11 fracture types were noted in male patients, and 18 types in female patients. Data on the average age of male patients and female patients of the 2nd (older) age group for the established types of fractures according to the AO / ASIF classification are presented in Fig. 8. 


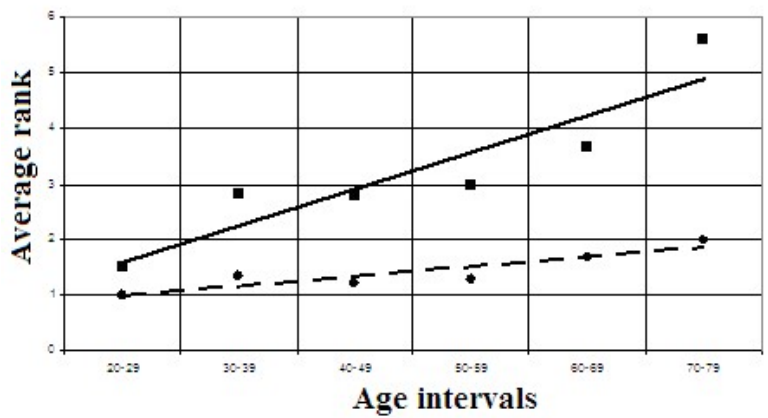

Fig. 7 - Dependences of mean ranks according to the classification of AO / ASIF and types A, B, C for age intervals in male patients

The values of the average ages of men and women of the 2nd group are indicated by circles and triangles, respectively. Fractures of types A32 and C13 were not found in women in group 2. Types A2.3, B1.3, B2.1, B3.2, B3.3, C3.2 and C3.3 were not found in men. Therefore, the corresponding markers in Fig. 8 were not installed. However, the initial data at our disposal made it possible to establish the presence of a general trend towards an increase in the average age both in female patients of the 2 nd group and in male patients with a displacement of the fracture line to the distal part of RB.

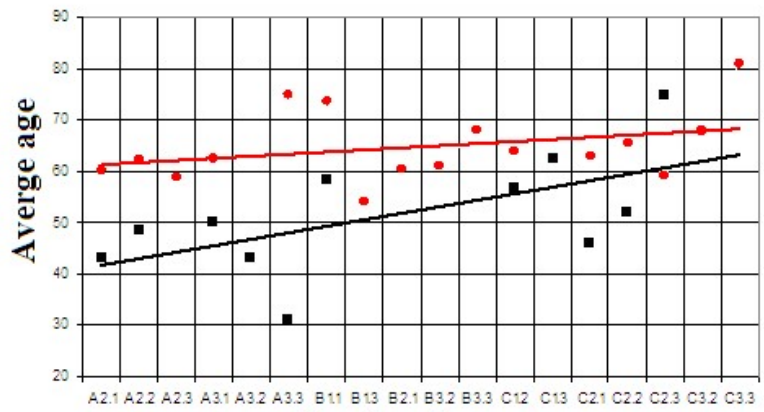

Fracture type

Fig. 8 - Dependence of the average age of patients on the fracture type

The found dependences are described by the following equations: for women of the 2 nd age group (top line) $x=2.44 y-148.27$, for men (bottom line) $x=0.79 y-32.27$.

To obtain the relationship between age intervals and fracture types A, B, $C$ for men and women separately, the data in Table 1 is used. Here, as a null hypothesis $H_{0}$, the assumption that there is no connection between the gender of patients and the type of age group is accepted. 
The coefficient of mutual conjugation or the polychoric indicator of connection proposed by C. Pearson [9] is used:

$$
C=\sqrt{\frac{\chi^{2}}{\chi^{2}+N}}=\sqrt{\frac{\varphi^{2}}{\varphi^{2}+1}}
$$

where $\varphi^{2}=\sum_{i=1}^{n} \frac{f_{x y}^{2}}{\sum f_{x} \sum f_{y}}-1$ is the value in which $f_{x y}$ it denotes the frequencies in the cells of the multi-field correlation table, $\sum f_{x}$ and $\sum f_{y}$ are the sums of frequencies by rows and columns; $N=\sum f_{x}+\sum f_{y}$ is the total sum of frequencies equal to the sample size; $n=n_{x}+n_{y}$ is the sum of rows and columns.

Substituting the values from table 1 , we get for men $\varphi^{2}=0.2157$, $C=0.4212$.

Formula for coefficient with Chuprov's correction:

$$
K^{2}=\frac{\chi^{2}}{N \sqrt{\left(n_{x}-1\right)\left(n_{y}-1\right)}}=\frac{\varphi^{2}}{\sqrt{\left(n_{x}-1\right)\left(n_{y}-1\right)}} .
$$

We calculate: $K=\sqrt{\frac{0.2157}{\sqrt{(3-1)(6-1)}}}=0.2612$.

The value of the coefficient shows the presence of a weak relationship between age intervals and fracture types $A, B, C$ for male patients.

Criterion for evaluating the null hypothesis is $\chi_{\mathrm{f}}^{2}=N \varphi^{2}=47 \times 0.2157=10.14, \chi_{s t}^{2}=18.31$ for the number of degrees of freedom $k=(3-1)(6-1)=10$ and the level of significance $\alpha=5 \%$ (for the minimum $\chi_{s t}^{2}$ ). Since $\chi_{\mathrm{f}}^{2}<\chi_{s t}^{2}$, the null hypothesis $H_{0}$ is confirmed. Therefore, for men, no connection was found between age intervals and fracture types $A, B, C$ at $(P<0.05)$.

For female patients we get the next values: $\varphi^{2}=0.0436, C=0.2044$, $K=\sqrt{\frac{0.0436}{\sqrt{(3-1)(7-1)}}}=0.1122$. The value of the coefficient $K$ shows the presence of a weak relationship between age intervals and types of fractures A, B, C for female patients. 
Criterion for evaluating the null hypothesis is $\chi_{\mathrm{f}}^{2}=N \varphi^{2}=271 \times 0.0436=11.82 \sqrt{b^{2}-4 a c}, \chi_{s t}^{2}=21.03$ for the number of degrees of freedom $k=(3-1)(7-1)=12$ and the level of significance $\alpha=5 \%$ (for the minimum $\chi_{s t}^{2}$ ). Since $\chi_{\mathrm{f}}^{2}<\chi_{s t}^{2}$, the null hypothesis $H_{0}$ is confirmed. Therefore, for female patients, there was also no connection between age intervals and fracture types $A, B, C$ at $(P<0.05)$.

It is known that osteoporosis as a systemic disease of the skeleton manifests itself, approximately, from the age of 50 [14]. To study the influence of the time factor on the integrity injury of the studied biomechanical structure and its relationship with gender, all patients were divided into two age groups: group 1 (20 - 49 years old) - 99 patients ( 70 women and 29 men) and group 2 (50 years and older) 219 patients (201 women and 18 men). The four-field correlation table was composed (Table 2).

Table 2 - Quadruple correlation table

\begin{tabular}{|l|c|c|c|}
\hline \multirow{2}{*}{$\begin{array}{c}\text { Sex of } \\
\text { patients }\end{array}$} & \multicolumn{2}{|c|}{ Age oroups } & \multirow{2}{*}{ Total } \\
\cline { 2 - 3 } & Group 1 & Group 2 & \\
\cline { 1 - 4 } Male & $a=29$ & $b=18$ & 47 \\
\cline { 1 - 1 } & $c=70$ & $d=201$ & 201 \\
\hline Total & 99 & 219 & $n=318$ \\
\hline
\end{tabular}

Let us use the formula for calculating the Pearson association coefficient, taking into account the Yates correction for the continuity of variation, in order to measure the closeness of the relationship between qualitative characteristics [9] (gender of patients and type of age group):

$$
r_{A}=\frac{|a d-b c|-n / 2}{\sqrt{(a+b)(c+d)(a+c)(b+d)}}
$$

where $a, b, c, d$ is the number of correlated groups (variant), distributed among the cells of table $1, n$ is the total number of roentgenograms.

As a null hypothesis $H_{0}$, we accept the assumption that there is no connection between the gender of patients and the type of age group.

Substituting the values into the formula (1), we get $r_{A}=0.265$. The found value of the sample association coefficient $r_{A}$ indicates the presence of a weak correlation between the gender of patients and the type of age group.

The reliability of the obtained sample association coefficient was assessed by the value of the Pearson criterion $\chi^{2}$. The hypothesis $H_{0}$ is rejected if $\chi_{\mathrm{f}}^{2}=n r_{A}^{2} \geq \chi_{s t}^{2}$ for the accepted level of significance $\alpha$ and the number of degrees of freedom $k=(2-1)(2-1)=1$. The significance of the association coefficient $r_{A}=0.265$ calculated in this way gives 
$\chi_{\mathrm{f}}^{2}=318 \cdot(0.265)^{2}=22.34$. This value significantly exceeds the critical level $\chi_{\text {st }}^{2}=10.83$ for $\alpha=0.1 \%$ and $k=1$. Therefore, the hypothesis $H_{0}$ is rejected at the $0.1 \%$ significance level $(P<0.001)$.

The significance of the result $r_{A}=0.265$ was also verified using the Student $t$-criterion. The null hypothesis is rejected if $t_{\mathrm{f}}=\frac{r_{A} \sqrt{n-2}}{\sqrt{1-r_{A}^{2}}} \geq t_{s t}$ for the accepted significance level $\alpha$ and the number of degrees of freedom $k=n-2$. The assessment of the reliability of the coefficient $r_{A}=0.265$ according to the value of Student $t$-criterion was $t_{\mathrm{f}}=4.89$. For $\alpha=0.1 \%$ and number of degrees of freedom $k=318-2=316$, the critical point $t_{s t}=3.29$. Because $t_{\mathrm{f}}>t_{s t}$, the null hypothesis is also rejected at a high level of significance $(P<0.001)$.

Let's check the truth of the null hypothesis $H_{0}$ using the formula for calculating the association coefficient Yula $r_{Q}$ [9]:

$$
r_{Q}=\frac{a d-b c}{a d+b c} .
$$

We use the formula to calculate the statistical error $s_{r_{Q}}$ through the Yule association coefficient $r_{Q}$ :

$$
s_{r_{Q}}=\frac{1-r_{Q}^{2}}{2} \sqrt{\frac{1}{a}+\frac{1}{b}+\frac{1}{c}+\frac{1}{d}} .
$$

Substituting the values $a, b, c$ and $d$ from table 1 , we get $r_{Q}=0.645$ and $s_{r_{Q}}=0.097$. The assessment of the reliability of the Yule association coefficient $r_{Q}=0.645$ according to the value of Student $t$-criterion was $t_{\mathrm{f}}=\frac{r_{Q}}{s_{r_{Q}}}=6.67$. For the number of degrees of freedom $k=316$ and significance level $\alpha=0.1 \%$, the critical point is $t_{s t}=3.29$. Since $t_{\mathrm{f}}>t_{s t}$, the null hypothesis $H_{0}$ is rejected at the $0.1 \%$ significance level $(P<0.001)$.

Thus, the presence of a weak correlation between the gender of patients and the type of age group is confirmed.

Using the $A B C$ scheme, the histogram of the distribution of the number of female patients in group 2, the total number of female and male patients depending on the type of fracture A, B, C were obtained (Fig. 9). 


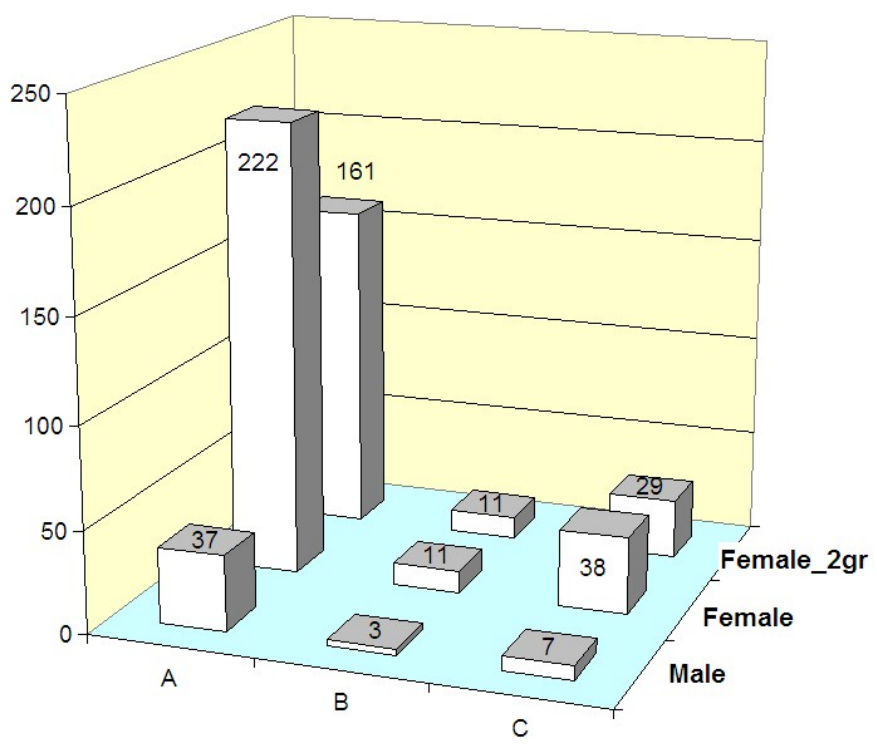

Fig. 9 - Histogram of the distribution of the total number of male, female and female patients of group 2, by fracture types A, B, C

Rebuilding the histogram in Fig. 9 for the relative number of patients in each considered category, as well as adding the distribution of the total number of patients, the diagram in Fig. 10 was constructed.

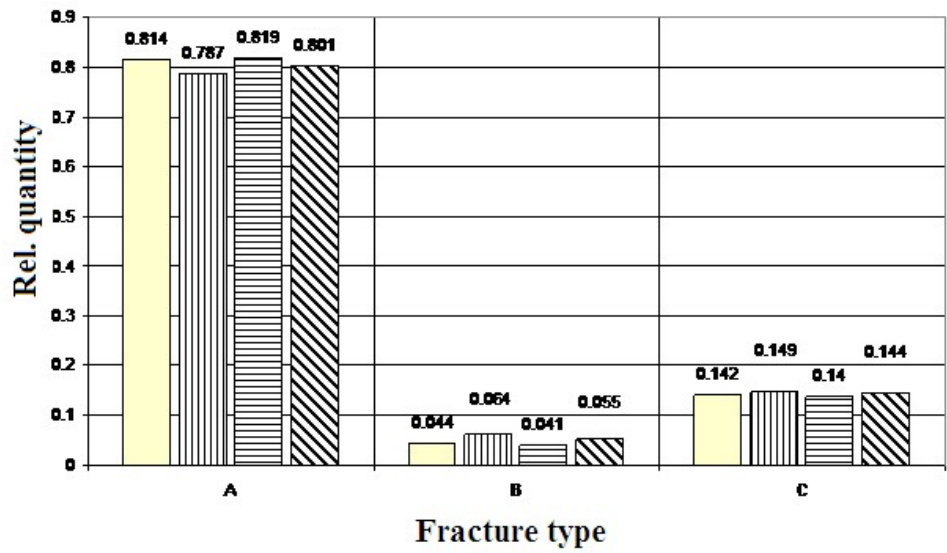

Fig. 10 - Diagram of the distribution of the relative number of all patients, male, female and female patients of the 2 nd group, by types of fractures A, B, C

In Fig. 10 the relative quantity of the all patients are marked by unhatched columns, by vertical hatch - the male patients, and by horizontal hatch - the female patients of second age group. 
Note a similarity of relative values of the all patient categories for each fracture types. Thus, the maximum values for A-type fracture is $3.2 \%$, for Btype fracture $-2.3 \%$ and for C-type fracture $-0 / 9 \%$.

By means of calculating the average relative values for the all patient categories under examination in can be obtained next ratio: the relative patient quantities are distributed to the fracture types A, B, C as $0.809,0.049$, 0.142 . On the base of our initial data and by comparing achieved values with ones for the all patient amount, it can be made the following. The fracture of type A occurs in $81 \%$ of patients, B-type fracture occurs in $5 \%$ and C-type fracture - in $14 \%$ of patients.

Note a similarity of relative values of the all patient categories for each fracture types. Thus, the maximum values for A-type fracture is $3.2 \%$, for Btype fracture $-2.3 \%$ and for C-type fracture $-0 / 9 \%$.

By means of calculating the average relative values for the all patient categories under examination in can be obtained next ratio: the relative patient quantities are distributed to the fracture types A, B, C as $0.809,0.049$, 0.142 . On the base of our initial data and by comparing achieved values with ones for the all patient amount, it can be made the following. The fracture of type A occurs in $81 \%$ of patients, B-type fracture occurs in $5 \%$ and C-type fracture - in $14 \%$ of patients.

In $[13,14]$ the treatment results of 128 patients were investigated. The Atype fracture occurs in 43 cases (33.6\%), B-type fracture - in 52 cases $(40.6 \%)$ and C-type fracture - in 33 cases $(25.8 \%)$.

In [10] on the base of 85 patients ( 8 male and 77 female) the following distribution of fractures were revealed: A-type fracture -31 patients $(36.5 \%)$, B-type fracture - 28 patients $(32.9 \%)$ and C-type fracture - in 26 cases (30.6\%).

In [17] the next structure radius fracture was published. In group I with 106 patients (37 male, 68 female) the A-type occurs 34 times (32.1\%), Btype -7 times (6.6\%), C-type -65 times (61.3\%). In group II with 98 patients (25 male, 73 female) such result was obtained: the A-type fracture - 57 cases (58.2\%), B-type -7 cases $(7.1 \%)$ and C-type - $34(34.7 \%)$. The cases with surgery treatment were studied in this work.

Conclusions. A study of external force influence on integrity damage of an element of biomechanical system is fulfilled. The radius bone is regarded as the element under examination. The time influence i.e. patient age on the fracture peculiarities is taken into account. The following results are obtained.

1. The dependency of fracture type on time influence has been established.

2. The weak statistical dependency between gender factor influence and time factor duration was revealed.

3. The structure (distribution) of integrity damage of radius bone according to fracture type was described.

4. It is possible to use the adaptive approach to damaged element rehabilitation on the base of obtained dependency of fracture type change and time factor durability for more numerous part of sampling. 


\section{REFERENCES}

1. Alexandrov T.I., Prokhorenko V.M., Chorny S.I. The total wrist joint replacement: literature review and evaluation of own observations // Electron scientific review "Modern problems of science and education". 2017. No 4.

https://science-education.ru/ru/issue/view?id=147 (in Russian).

2. Angarskaya E.G. Colles' fracture // Sibirsky meditzinsky zhurnal. 2007. No 3. P. 106-108. (in Russian).

3. Bukovska Yu.V. Role of spiral computer tomography in damage diagnostics of radiocarpal joint and wrist // Radiology - practice. 2007. No 2. P. 27-33. (in Russian).

4. Bukovska Yu.V. Possibilities of magnetic-resonance tomography in damage diagnostics of bone structures of radiocarpal joint and wrist and their complication Radiology - practice. 2007. No 2. P. 42-51. (in Russian).

5. Gubler E.V., Genkin A.A. An application of non-parametrical statistic criteria in medical and biological investigations. Leningrad.: Meditzina, 144 p. (in Russian).

6. Kapandji A.I. Upper limb. Joint physiology. Moscow: Eksmo, 2009. 368 p. (in Russian).

7. Khominets V.V., Tkachenko M.V., Syrtsov V.V., Ivanov V.S. Comparative analysis of treatment tecHnique in patients with distal radius fractures // Traumatology and orthopedy in Russia. 2015. No 2. P. 5-15. (in Russian)

8. Korzch N.A., Gerasimenko S.I., Klimovitzki V.G., Loskutov A.E., Romanenko K.K., Gerasimenko A.S., Kolomietz E.N. Distribution of bone fractures and treatment results in the Ukraine (clinical-epidemiological investigation) // Orthopedy, traumatology and prosthetics. 2010. No 3. P. 5-14. (in Russian).

9. Lakin G.F. Biometry. Moscow: Visshaja shkola, 1990. 352 p. (in Russian).

10. Matveev R.P., Bragina S.V., Shneiveis A.M. Differentiated approach to repair of displaced distal radial metaepiphyseal fractures // Genius of orthopedy. Vol. 23. 2017. No 4. P. 396-400. (in Russian).

11. Müller M.E., Nazarian S., Koch P. Classification AO des Fractures. 1. Les os longs. Berlin, Heidelberg, New York: Springer-Verlag, 1987. 78 p.

12. Müller M.E., Nazarian S., Koch P., Schtzker J. The Comprehensive Classification of Fractures of Long Bones. Heidelberg, New York: Springer-Verlag, 1990. 91 p.

13. Naumenko L.Yu., Vinnik A.A., Pogrebnoy O.V. Analysis of results treatment aged patients with the damaged distal radius epimetaphysis // Ukranian bulletin of medical-social examination. Dnepropetrovsk. 2012. № 1. (3). P. 101-110. (in Russian).

14. Naumenko L.Yu., Vinnik A.A., Pogrebnoy O.V. Restorative treatment of patients with injury of distal metaepiphysis of radius // Bulletin of Orthopedy, traumatology and prosthetics. Kuiv. 2012. No 2. (73). P. 26-29. (in Russian).

15. Pogrebnoy O.V. Modeling of element damage of biomechanical system under action of external force factors // Problems of Computational Mechanics and Strength of Structures: Col. of sci. art. Dnipro: Lira, 2019. Vol. 29. P. 246-259.

16. Rosental T.D., Bozentka D.J., Kats M.A. et al. Evaluation of the sigmoud notch with computed tomography following intraarticular distal radius fracture // The J. of Hand Surgery 2001. Vol. 26A. No 2. P. 244-251.

17. Semenkin O.M., Izmalkov S.N. Errors and complications in the surgical treatment of patients with distal radius fractures // Traumatology and orthopedy in Russia. 2014. No 4. P. 47-56. (in Russian)

18. Tashtaev S.K, Martynenko N.P., Yakupov A.B. Treatments fractures of distal metaepiphysis of radial bone at advanced age. (Literature review) // Science and medical health. 2014. No 3. P. 12-14. (in Russian) 


\section{О. В. Погрібний \\ МОДЕЛЮВАННЯ ВПЛИВУ ЗОВНІШНІХ СИЛОВИХ ДІЙ І СТРУКТУРНИХ ФАКТОРІВ НА ПОРУШЕННЯ ЦІЛІСНОСТІ ЕЛЕМЕНТУ БІОМЕХАНІЧНОЇ СИСТЕМИ}

Вивчені особливості порушення цілісності елементу біомеханічної системи, що знаходиться під дією зовнішніх силових факторів. Як біомеханічна система розглядався променезап'ястковий суглоб, що входить до складу кистьового суглоба. Елементом променезап'ясткового суглоба, схильного до порушення цілісності або значного пошкодження, була променева кістка. При цьому враховувалася зміна структури об'єкту залежно від часу. Початковими (первинними) даними при моделюванні були рентгенограми пошкоджених ділянок елементу біомеханічної системи. Досліджено вплив гендерного фактору. Встановлені залежності типів пошкоджень для груп пацієнтів, що вивчалися.

Ключові слова: моделювання, біомеханічна система, променезап'ястковий суглоб, променева кістка, рентгенограма, перелом в класичному місці, типи переломів, остеопороз.

Пошкодження променезап'ясткового суглоба і кисті $€$ частими травмами скелета, їх частка складає не менше $35 \%$ від загальної кількості травм кінцівок. До того ж у багатьох випадках вони ведуть до тривалого обмеження працездатності, а іноді і до інвалідності. Постраждалими $є$ як люди похилого віку, які ведуть активний спосіб життя, так і молодші особи, які зазнають високоенергетичних травм. При цьому спостерігається стійка тенденція збільшення числа випадків даних травм серед пацієнтів старше 50 років, особливо жінок. Одним із сприяючих чинників зростання частоти переломів в похилому i старечому віці $\epsilon$ остеопороз. Важливим чинником ризику переломів слід вважати збільшення числа падінь у літніх людей, які відбуваються в побутових умовах з висоти власного зросту.

Традиційно всі переломи дистального метаепіфізу променевої кістки ділять на розгинальні (переломи Коллеса), згинальні (переломи Сміта) і вколочені. В даний час в клінічній практиці широкого поширення набула класифікація AO/ASIF, яка дозволяє визначити не тільки тип перелому, але і служить алгоритмом вибору лікувальної тактики.

Мета роботи полягає в моделюванні особливостей порушення цілісності елементу біомеханічної системи, що знаходиться під впливом зовнішніх силових дій і внутрішніх чинників.

Початковий експериментальний матеріал включав 318 рентгенограм пацієнтів з пошкодженнями дистального метаепіфрізу променевої кістки. Загальну кількість пацієнтів склали 47 чоловіків і 271 жінка. Пошкодження систематизувалися згідно класифрікації AO/ASIF, а також за спрощеною схемою розподілу $\mathrm{ABC}$, згідно якої розділення здійснювалося за типами переломів: А - навколосуглобові переломи, В - неповні внутрішньосуглобові і C - повні внутрішньосуглобові.

Проведено вивчення впливу зовнішніх силових чинників на порушення цілісності елементу біомеханічної системи, в якості якого 
виступала променева кістка. Враховувався вплив фактору часу. тобто віку пацієнтів, на особливості переломів.

Висновки. В результаті дослідження отримані наступні результати.

1. Встановлена залежність типу пошкодження елементу біомеханічної системи від впливу чинника часу.

2. Встановлена наявність слабкої статистичної залежності між впливом гендерного чинника і тривалістю дії фактору часу.

3. Описана структура (розподіл) порушень цілісності елементу біомеханічної системи за типами пошкоджень.

4. Виявлена залежність зміни типу пошкодження цілісності елементу біомеханічної системи від тривалості дії тимчасового фактору для значної (найбільш численної) частини досліджуваної вибірки дозволяє застосувати адаптивний підхід до відновлення пошкодженого елементу.

УДК 539.3:612.76

\author{
О. В. Погребной
}

\title{
МОДЕЛИРОВАНИЕ ВЛИЯНИЯ ВНЕШНИХ СИЛОВЫХ ВОЗДЕЙСТВИЙ И СТРУКТУРНЫХ ФАКТОРОВ НА НАРУШЕНИЕ ЦЕЛОСТНОСТИ ЭЛЕМЕНТА БИОМЕХАНИЧЕСКОЙ СИСТЕМЫ
}

Изучены особенности нарушения целостности элемента биомеханической системы, находящейся под действием внешних силовых факторов. В качестве биомеханической системы рассматривался лучезапястный сустав, входящий в состав кистевого сустава. Элементом лучезапястного сустава, подверженного нарушению целостности или значительному повреждению, являлась лучевая кость. При этом учитывалось изменение структуры изучаемого объекта в зависимости от времени. Исходными (первичными) данными являлись рентгенограммы повреждённых участков элемента биомеханической системы. Исследовано влияние гендерного фактора. Установлены зависимости типов повреждений для изучаемых групп пациентов.

Ключевые слова: моделирование; биомеханическая система; лучезапястный сустав; лучевая кость; рентгенограмма; перелом в классическом месте; типы переломов; остеопороз.

Oles Honchar

Dnipro National University,

Dnipro, Ukraine

Received by the Editorial Board 24.06.2020 